Estudios Constitucionales, Año 10, No 1, 2012, pp. 339 - 372.

ISSN 0718-0195

Centro de Estudios Constitucionales de Chile Universidad de Talca

"Libertad religiosa y objeción de conciencia en el derecho constitucional argentino"

Fernando Arlettaz

\title{
LIBERTAD RELIGIOSA Y OBJECIÓN DE CONCIENCIA EN EL DERECHO CONSTITUCIONAL ARGENTINO ( $\left.{ }^{1}\right)$ \\ Religious Freedom and Conscientious Objection in Argentinian Constitutional LaW
}

\author{
FERnANdo ARLETTAZ ${ }^{2}$ \\ Universidad de Zaragoza \\ fernandoarlettaz@yahoo.com.ar
}

RESUMEN: Este artículo aborda los aspectos más relevantes del derecho a la libertad religiosa en el derecho constitucional argentino. En una primera parte, se exponen los antecedentes del derecho en la historia constitucional argentina y se estudia el derecho en si mismo, considerando su contenido y sus límites, asi como su relación con el principio de igualdad. Se hace una especial mención a la situación de los grupos religiosos minoritarios. En una segunda parte se profundiza sobre un aspecto concreto de la libertad religiosa, la objeción de conciencia, explicando su origen jurisprudencial, su alcance y sus limites. El articulo recurre a las fuentes normativas que regulan el derecho (el texto constitucional, la legislación ordinaria y la jurisprudencia, en particular la de la Corte Suprema de Justicia) asi como a la opinión de la doctrina especializada.

ABSTRACT: The subject of this article is religious freedom in Argentinian constitutional law. In the first part, the paper exposes the precedents of the right in the Argentinian constitutional history, and considers its content, its limits and its relation with the equality principle. The situation of religious minorities is specially mentioned. In the second part, one aspect of the right is emphasized: conscientious objection. Its jurisprudential origin, its scope and its limits are then explained. The paper refers to the main normative sources in this matter (the constitutional text itself, ordinary statutes and case-law, in particular Supreme Court case-law), as well as the opinions of the specialized authors.

PALABRAS CLAVE: libertad religiosa, objeción de conciencia, derecho constitucional argentino.

KEY-WORDS: religious freedom, conscientious objection, Argentinian constitutional law.

\section{INTRODUCCIÓN}

El presente trabajo busca exponer una perspectiva general sobre la libertad religiosa en el derecho constitucional argentino. Para ello, parte de las disposiciones

\footnotetext{
${ }^{1}$ Artículo recibido el 5 de octubre de 2011 y aprobado el 18 de abril de 2012.

${ }^{2}$ Abogado por la Universidad Católica Argentina y Diploma de Estudios Avanzados en Filosofía del Derecho por la Universidad de Zaragoza (España). Doctorando en Sociología Jurídica e Instituciones Políticas e investigador del Programa de Formación del Profesorado Universitario (Ministerio de Educación) en la Universidad de Zaragoza. Autor de artículos especializados sobre los aspectos jurídicos y políticos del fenómeno religioso. Este artículo ha sido realizado en el contexto del Proyecto Consolider Ingenio 2010 El Tiempo de los Derechos (CSD 2008-0007).
} 
del texto constitucional, tal como son generalmente interpretadas por la doctrina científica. Se hace también mención a la jurisprudencia de la Corte Suprema de Justicia de la Nación, máximo órgano de interpretación constitucional. Aunque sus sentencias en esta materia no son abundantes, pueden hallarse en los casos resueltos por este órgano jurisdiccional serias argumentaciones respecto de la exégesis de las disposiciones mencionadas. Esta visión se complementa con el recurso a otros textos normativos y la jurisprudencia de algunos tribunales de rango inferior a la Corte Suprema.

Algunas aclaraciones previas resultan necesarias. En primer lugar, dado que no es éste un análisis que pertenezca al ámbito de la historia del derecho, se ha reducido el espacio destinado a los antecedentes históricos, de modo que sólo se hace una mención genérica a los mismos, aunque la historia del derecho en cuestión (como la historia de los derechos en general) sea mucho más rica y compleja. En segundo lugar, hay que tener presente que se hace aquí un estudio de la libertad religiosa, y no de todas las disposiciones del derecho constitucional argentino relativas a la cuestión religiosa. Por ello sólo hay una mención general al régimen del artículo 2 y sus concordantes, relativos al estatuto especial de la Iglesia Católica. Finalmente, dado que la República Argentina ha adoptado la forma de un Estado federal, cada una de las Constituciones provinciales podría también ser estudiada desde el ángulo de los derechos subjetivos públicos por ellas consagrados. Este trabajo, en cambio, se enfoca prioritariamente en el ámbito del derecho constitucional federal.

\section{LiBERTAD RELIGIOSA}

\subsection{Consideraciones generales, antecedentes históricos y evolución normativa}

La Constitución argentina hoy en vigor, sancionada en 1853, garantiza desde su misma génesis la libertad religiosa, mediante la inclusión en el artículo 14 (que enumera los derechos civiles fundamentales) del derecho de todos los habitantes del territorio de profesar libremente su culto $^{3}$. Mediante la terminología de la libertad de cultos, característica del debate constitucional decimonónico, la Constitución introduce el derecho aquí tratado, considerado por los constituyentes como una herramienta fundamental en el proyecto de formación de la nueva Nación mediante la incorporación de inmigrantes europeos. En efecto, la propia Constitución se interesó en prescribir como deber del gobierno federal el de promover la inmigra-

${ }^{3}$ Artículo 14 de la Constitución de la Nación Argentina: "Todos los habitantes de la Nación gozan de los siguientes derechos conforme a las leyes que reglamenten su ejercicio; a saber: [...] de profesar libremente su culto $[\ldots] "$. 
ción europea ${ }^{4}$, para lo cual era necesario garantizar que los nuevos habitantes que habrían de llegar al territorio pudieran gozar de la libertad de practicar su propia religión haya sido ésta la católica (como era la mayor parte de la población por entonces) o haya sido ésta diferente de la católica.

El texto del artículo proviene del proyecto constitucional del iuspublicista Juan Bautista Alberdi, figura clave en la formación política del Estado argentino. Alberdi, interesado en promover la llegada de inmigración, en particular anglosajona de religión protestante, veía la libertad religiosa como un elemento clave. Existía, por otra parte, el antecedente del Tratado de Amistad, Comercio y Libre Navegación firmado con Inglaterra en 1825 por el que se había otorgado la libertad de cultos a los nacionales ingleses que residieran en territorio argentino. Los dos textos constitucionales que habían precedido a la Constitución de 1853, los de 1819 y 1826, por el contrario, habían sido mucho más restrictivos respecto de este derecho5.

La libertad de cultos del artículo 14 fue complementada por otras disposiciones, que siguen hoy en vigor: el artículo 20, que reitera el derecho en relación con los extranjeros ${ }^{6}$, y el artículo 19, que protege las acciones privadas que no afectan al orden y a la moral pública ni perjudican a terceros ${ }^{7}$, de modo que delinea un ámbito de reserva de la libertad personal y reconoce el principio de intimidad ${ }^{8}$. Las acciones privadas mencionadas por el art. 19 son tanto las acciones privadas internas (acciones intimas, actos realizados en absoluta privacidad, de los que nadie puede percatarse) como las acciones privadas externas (actos que trascienden al sujeto que los realiza, pero que no ofenden la moral y el orden públicos ni perjudican a terceros). Por ello es que las conductas motivadas por un sentido religioso, aunque sean externas y en este sentido públicas, siguen estando protegidas por el artículo 19 en tanto no ofendan los citados principios ni causen daño a terceros.

\footnotetext{
${ }^{4}$ Artículo 25 de la Constitución de la Nación Argentina.

${ }^{5}$ La Constitución de 1819, aunque aseguraba la protección de las acciones privadas que no perjudicaran el orden público o los intereses de terceros (artículo CXII), establecía que todos los habitantes del territorio debían respeto a la religión católica, cualquiera que sean sus opiniones privadas (artículo I). Disposiciones semejantes habían existido en la Constitución de 1826 (artículos 162 y 3, respectivamente).

${ }^{6}$ Artículo 20 de la Constitución de la Nación Argentina: "Los extranjeros gozan en el territorio de la Nación de todos los derechos civiles del ciudadano; pueden [...] ejercer libremente su culto [...]".

7 Artículo 19 de la Constitución de la Nación Argentina: "Las acciones privadas de los hombres que de ningún modo ofendan al orden y a la moral pública, ni perjudiquen a un tercero, están sólo reservadas a Dios, y exentas de la autoridad de los magistrados. Ningún habitante de la Nación será obligado a hacer lo que no manda la ley, ni privado de lo que ella no prohíbe".
}

${ }^{8}$ Gelli (2005), pp. 136-137. 
Las sucesivas reformas de la Constitución de 1853 (1860, 1866, 1898, 1949, 1972 y 1994) respetaron la cláusula de la libertad de cultos. De hecho, puede decirse que a pesar de los vaivenes político-institucionales que sacudieron al país en el siglo XX, y que implicaron en muchos casos violaciones gravísimas a derechos humanos fundamentales, la libertad religiosa fue bien mantenida en la Argentina. Desde luego, hubo algunos casos específicos en los que algunos grupos se vieron afectados, pero fueron más bien aislados. Este respeto a una tradición jurídica garante de las conciencias de los ciudadanos parece haber sido sostenido y reforzado por un clima social de mutua tolerancia y respeto entre las confesiones.

La innovación más importante en el derecho constitucional argentino, en lo que respecta a la libertad religiosa ( $\mathrm{y}$ a los derechos fundamentales en general, podría decirse) fue el reconocimiento de jerarquía constitucional a una serie de tratados y declaraciones internacionales en materia de derechos humanos, que realizó la reforma constitucional de $1994^{\circ}$. Desde esta reforma, los documentos internacionales expresamente mencionados por el texto constitucional, así como los que con posterioridad el Congreso, por mayoría cualificada, decida incorporar a esa lista, tienen el mismo rango que el texto constitucional y deben entenderse complementarios de los derechos y garantías en él reconocidos.

De especial significación entre los instrumentos a los que la reforma de 1994 ha dado rango constitucional es la Convención Americana de Derechos Humanos. En su ámbito, la Corte Interamericana de Derechos Humanos ha desarrollado la figura del control de convencionalidad en virtud del cual las disposiciones de derecho interno de los Estados parte en la Convención deben pasar por el tamiz de ésta, de modo que su efecto útil no se vea mermado por la aplicación de leyes internas contrarias a sus disposiciones. Así, del mismo modo que los jueces internos realizan un control de constitucionalidad al comparar el contenido de las normas infraconstitucionales con el contenido de las normas constitucionales,

\footnotetext{
9 El artículo 75 inciso 22 de la Constitución de la Nación Argentina otorga jerarquía constitucional a diez documentos internacionales. De ellos tienen normas relevantes en materia de libertad religiosa: Declaración Universal de Derechos Humanos (artículos 18, 2.1 y 26.2), Pacto Internacional de Derechos Civiles y Políticos (artículos 18, 2.1, 4.1, 20.2, 24.1, 26 y 27); Pacto Internacional de Derechos Económicos, Sociales y Culturales (artículos 2.2, 13.1 y 13.3); Convención para la Eliminación de todas las formas de Discriminación contra la Mujer; Convención de los Derechos del Niño (artículos 14, 2.1, 20.3, 29.1 y 30); Declaración Americana de Derechos y Deberes del Hombre (artículos III y XXII); Convención Americana de Derechos Humanos (artículos 12, 1.1, 13.5, 16.1, 22.8 y 27.1). El artículo II de la Convención para la Prevención y Sanción del Delito de Genocidio incluye al grupo religioso como posible sujeto pasivo de este delito. También son relevantes los artículos 1 y 5 d vii de la Convención para la Eliminación de todas las formas de Discriminación Racial y el artículo 1 de la Convención contra la Tortura y otros Tratos o Penas Crueles, Inhumanos o Degradantes. La protección de las minorías (artículo 27 del Pacto Internacional de Derechos Civiles y Políticos y artículo 30 de la Convención de Derechos del Niño) resulta aplicable a las minorías religiosas.
} 
han de realizar un control de convencionalidad comparando el derecho interno con el derecho internacional convencional ${ }^{10}$. Al realizar esta comparación, los jueces internos han de tener en cuenta no sólo el texto del tratado en sí mismo, sino también la interpretación que de éste haya realizado la Corte Interamericana, intérprete último de la Convención ${ }^{11}$.

Por otra parte, el contenido de la libertad de cultos del artículo 14 debe leerse en relación con el artículo 2 del propio texto constitucional que reconoce desde 1853 el deber del gobierno federal de sostener el culto católico ${ }^{12}$ y que es resultado de los compromisos políticos alcanzados en el seno del Congreso Constituyente. La Constitución reconoce así a la Iglesia Católica una posición preeminente, que no llega sin embargo a ser la de una religión oficial. Esta posición preeminente sobre los demás grupos religiosos era además reforzada, en el texto original de 1853, por un conjunto de disposiciones relativas a la relación del Estado con la Iglesia Católica. Muchas de estas disposiciones perdieron efectividad después de la entrada en vigor del Acuerdo con la Santa Sede de 1966, y todas ellas fueron formalmente eliminadas del texto constitucional con la última reforma ${ }^{13}$.

Las relaciones del Estado Federal con la Iglesia Católica están reguladas por el Acuerdo entre la República Argentina y la Santa Sede de 1966. Aunque no vamos a hacer aquí mención a las normas de este Acuerdo que se refieren a las relaciones institucionales entre el Estado argentino y la Iglesia Católica, sí diremos que el mencionado concordato refuerza la protección de la libertad religiosa en relación con esta confesión. En efecto, el primer artículo garantiza a la Iglesia Católica el pleno y libre ejercicio de su poder espiritual, el libre y público ejercicio de su culto, así como de su jurisdicción para la realización de sus fines propios ${ }^{14}$.

\footnotetext{
${ }^{10}$ Hitters (2009), p. 110.

11 Albanese (2007), p. 1148.

${ }^{12}$ Artículo 2 de la Constitución de la Nación Argentina: "El Gobierno federal sostiene el culto católico apostólico romano". Este texto proviene de la Constitución de 1853, y permanece hoy a pesar de las sucesivas reformas de la Carta Magna. La Constitución de 1853 se apartó, en este aspecto, de los textos y proyectos constitucionales anteriores. Así, las constituciones de 1819 y 1826 reconocían a la católica como religión de Estado.

${ }_{13}$ Ver los artículos 89 (antiguo 76), 93 (antiguo 80), antiguo 86 inciso 8 hoy suprimido, antiguo 86 inciso 9 hoy suprimido, antiguo 67 inciso 19 hoy suprimido, 75 inciso 17 (antiguo 67 inciso 15) y antiguo 67 inciso 20 hoy suprimido; todos de la Constitución de la Nación Argentina. Se trataba de las derivaciones del Regio Patronato Indiano, cuyo ejercicio reivindicaba el recién nacido Estado argentino. Véase al respecto Gramajo (2007), p. 66.

${ }^{14}$ Artículo I del Acuerdo entre la Santa Sede y la República Argentina: "El Estado Argentino reconoce y garantiza a la Iglesia Católica Apostólica Romana el libre y pleno ejercicio de su poder espiritual, el libre y público ejercicio de su culto, así como de su jurisdicción en el ámbito de su competencia, para la realización de sus fines específicos". Ver al respecto Navarro Floria (2011).
} 
Debido al carácter federal del Estado argentino, cada una de las provincias que constituyen el Estado se da a sí misma su propia Constitución y se rige por ella. Las Constituciones provinciales tienen normas que, en términos similares a la Constitución Nacional, garantizan la libertad religiosa. Más variable es la relación de los gobiernos provinciales con las organizaciones religiosas, también prevista en las respectivas Constituciones. Una provincia establece a la católica como religión oficial; algunas provincias establecen el principio de que el gobierno ha de sostener a la Iglesia Católica o cooperar con ella; dos provincias, sin establecer un tratamiento específico, reconocen la tradición cultural católica; algunas establecen un régimen de cooperación con las confesiones; otras finalmente consagran expresamente la separación o nada establecen, por lo que ha de interpretarse que adoptan tácitamente un régimen de separación ${ }^{15}$.

No existe en Argentina un cuerpo legal que gobierne en forma general y unitaria la libertad religiosa. Han existido sí varios proyectos al respecto ${ }^{16}$. Ante la ausencia de un texto legal unificado, los contornos del derecho han sido esbozados por la jurisprudencia y la doctrina de los autores a partir de los genéricos enunciados del texto constitucional y los documentos internacionales. Disposiciones complementarias pueden hallarse en los códigos civil y penal, así como en leyes especiales.

En lo que respecta a la efectividad del derecho, hay coincidencia en señalar que, más allá de los debates puntuales que pueden existir sobre la interpretación o los alcances de la libertad religiosa y las violaciones concretas que en algún caso pueden darse, la vigencia del derecho es real en Argentina. Así, el informe de la Secretaría de Estado de los Estados Unidos señalaba que en 2010 no se habían producido violaciones graves a la libertad religiosa (conversiones forzosas, privación de libertad por razones religiosas), que el gobierno promovía el diálogo interreligioso y que si bien habían existido algunos casos concretos de discriminación por parte de actores sociales, los líderes religiosos estaban comprometidos en la lucha contra los mismos ${ }^{17}$.

\footnotetext{
15 Sobre la libertad religiosa en las provincias puede consultarse Gentile (2007).

${ }^{16}$ En 1993 la Secretaría de Culto, a cargo de Miguel Ángel Centeno, presentó un proyecto que fue aprobado en el Senado, pero que nunca fue tratado en la Cámara de Diputados. En 1997 hubo otro proyecto originado en la Cámara de Diputados, pero que tampoco fue aprobado. En 2000 el Consejo Argentino para la Libertad Religiosa elaboró otro proyecto, que se vio frustrado por el fin de la actividad del Consejo a causa de la dimisión del presidente De la Rúa. En 2006 la Secretaría de Culto elaboró un anteproyecto de ley de organizaciones religiosas, que tampoco prosperó. En 2009 hubo dos proyectos, uno de la Secretaría de Culto (que a fines de 2009 no había sido todavía remitido al Congreso) y otro presentado por la diputada Hotton. Puede consultarse la evolución en Padilla (2009).

17 Bureau of Democracy, Human Rights and Labor - US Department of State (2011). Véase también el informe sobre Argentina del Relator Especial de las Naciones Unidas para la Libertad Religiosa (2002).
} 


\subsection{Sujetos protegidos}

La libertad religiosa corresponde en primer lugar a los individuos, y es reconocida a todos los habitantes de la Nación ${ }^{18}$. Pero la libertad religiosa tiene también una dimensión comunitaria: la formación de asociaciones con finalidades religiosas es una manifestación de esta libertad. Esto quiere además decir que la libertad religiosa es aplicable a las asociaciones religiosas ${ }^{19}$, las que pueden establecer normas internas que regulen las relaciones con sus miembros ${ }^{20}$.

La personalidad jurídica de las organizaciones religiosas tiene un régimen variable. La Iglesia Católica tiene reconocida personalidad de derecho público en el mismo Código Civil ${ }^{21}$. La doctrina, la jurisprudencia y la práctica administrativa han hecho extensiva esta personalidad de derecho público a cada una de las diócesis y circunscripciones territoriales y personales, a cada una de las parroquias que integran esta Iglesia y a otras personas jurídicas erigidas canónicamente por la autoridad eclesiástica ${ }^{22}$. La erección de cada diócesis, incluso las eparquías de rito oriental, ha sido expresamente reconocida por una ley o un decreto particular. Para las otras personas jurídicas canónicas no existen actos particulares de reconocimiento, pero la Secretaría de Culto certifica las constancias de erección otorgadas por la autoridad eclesiástica ${ }^{23}$. Las sociedades de vida apostólica y los institutos de vida consagrada tienen reconocida su personalidad en una ley especial, debiendo registrarse e inscribir sus estatutos y autoridades en el Registro de Institutos de Vida Consagrada, dependiente de la Dirección General del Culto Católico (en la Secretaría de Culto, Ministerio de Relaciones Exteriores, Comercio Internacional y Culto). La personalidad jurídica de éstas también es de derecho público ${ }^{24}$. Otros sujetos menores ligados a la Iglesia Católica pueden conformarse

18 Bermúdez (2007), pp. 92-93. Corte Suprema de Justicia de la Nación (CSJN): sentencia de 6 de abril de 1993, voto de los jueces Cavagna Martínez y Boggiano. CSJN: sentencia de 27 de noviembre de 1986, voto del juez Petracchi.

19 Bermúdez (2007), pp. 93-94. CSJN: sentencia de 6 de abril de 1993, voto de los jueces Cavagna Martínez y Boggiano.

${ }^{20}$ Así, por ejemplo, la Corte Suprema resolvió que no viola la libertad religiosa el hecho de que una sociedad de beneficencia que administra un cementerio exija, como requisito previo a la inhumación de un cadáver allí depositado y de acuerdo con sus normas internas, el pago de una determinada suma (CSJN: sentencia de 1959 [en la base de datos del alto tribunal sólo figura el año, pero no la fecha exacta de la sentencia]).

21 Artículo 33 del Código Civil: "Las personas jurídicas pueden ser de carácter público o privado. Tienen carácter público: [...]; 3) La Iglesia Católica; [...]”.

22 Navarro Floria (2007), pp. 247-248.

23 Navarro Floria (2007), p. 249.

24 Ley 24483 de 1995. Navarro Floria (2007), p. 250. 
como asociaciones civiles o simples asociaciones (las simples asociaciones son, en el derecho argentino, aquellas que actúan como tales en la vida civil, sin haberse constituido formalmente $)^{25}$.

Los grupos religiosos no católicos no tienen un régimen específico que regule su personalidad. Para ser reconocido como sujeto de derecho, la ley les impone la inscripción en el Registro Nacional de Cultos ${ }^{26}$ dependiente de la Dirección General del Registro Nacional de Cultos (en la ya mencionada Secretaría de Culto). Pero esta inscripción no confiere de por sí la personalidad, sino que es el paso previo para poder solicitar su reconocimiento como asociación civil. Hay que aclarar que la existencia de una persona jurídica no es un requisito indispensable para el ejercicio colectivo de la libertad religiosa (por ejemplo, no se podría prohibir a grupos de personas que se reunieran pacíficamente y de modo privado para practicar actos de su culto sobre la base de que no se han registrado como asociación religiosa), la existencia de una persona jurídica sí es necesaria para acceder al tráfico jurídico civil (por ejemplo, ser propietario de bienes inmuebles) y gozar de las exenciones impositivas previstas a favor de las organizaciones religiosas ${ }^{27}$.

La inscripción en este registro sólo es posible para aquellas organizaciones que tengan una finalidad propiamente religiosa. Esta finalidad surge del objeto que figura en sus estatutos o actas constitutivas. Ahora bien, para obtener la inscripción no basta con la mera declaración de la entidad respecto de su carácter religioso, sino que la Dirección del Registro Nacional de Cultos ha de comprobar fehacientemente la existencia real de la finalidad declarada. Obviamente, una vez comprobada la finalidad religiosa, la inscripción no está supeditada a ninguna valoración de oportunidad, mérito o conveniencia por parte de la autoridad administrativa ${ }^{28}$.

A pesar del régimen legal, la práctica da cuenta de una diversidad de situaciones. Algunas organizaciones han obtenido la doble inscripción. Pero muchas

\footnotetext{
${ }^{25}$ Artículos 33 y 46 del Código Civil, respectivamente.

26 Ley 21745 de 1978. Ésta fue precedida por otras normas (decreto 15829/46, decreto 31814, decreto 1127/59) que organizaron un tristemente célebre fichero de cultos no católicos. La ley actualmente en vigor está reglamentada por el decreto 2037 de 1979.

27 La ley del Registro Nacional de Cultos y su decreto reglamentario, ambos de técnica muy deficiente, disponen que la inscripción de los cultos no católicos es un requisito para su actuación dentro del territorio argentino. La imprecisión de los textos legales es grande (por ejemplo, el hecho de que un grupo de personas decidan reunirse para orar ¿implica una actuación de un grupo religioso y requiere por lo tanto una inscripción previa?) lo que dio pie a que gobiernos autoritarios prohibieran directamente la actividad de determinados grupos religiosos con el argumento de que no estaban inscriptos. Esta prohibición fue convalidada por la Corte Suprema que, por razones de tipo formal, no evaluó el fondo de su constitucionalidad (CSJN: sentencia de 14 de diciembre de 1978; CSJN: sentencia de 22 de diciembre de 1977).
}

${ }^{28}$ Chaves (2005), pp. 946-947. 
están inscritas en el Registro Nacional de Cultos y nunca se constituyeron como asociaciones civiles, por lo que son simples asociaciones. Otras han obtenido el reconocimiento como asociaciones o fundaciones, sin pasar antes por el Registro de Cultos. Finalmente, existen en la Argentina diferentes organizaciones nacidas al amparo de una legislación extranjera, e inscritas o no en el país ${ }^{29}$.

\subsection{Delimitación del contenido}

Aunque el texto constitucional se refiere a la libertad de profesar un culto, hay coincidencia en señalar que, a pesar de esta terminología restrictiva que corresponde a los usos corrientes en el pensamiento político del siglo XIX, hay que incluir en la cláusula constitucional la protección de lo que contemporáneamente se denomina libertad religiosa o de conciencia. Esta conclusión se refuerza por el hecho de que es precisamente esta terminología contemporánea la que aparece en los textos de los documentos constitucionales que, desde 1994, gozan de jerarquía constitucional en el derecho argentino.

Resta sin embargo establecer una delimitación conceptual entre las expresiones usuales en el ámbito de estudio referidas a derechos próximos entre sí como son la libertad religiosa, la libertad de conciencia y la libertad de pensamiento. No haremos aquí una detallada enumeración de las posturas existentes, tan tediosa como inútil, sino que nos limitaremos a mencionar dos posiciones teóricas que nos parecen relevantes.

Para una corriente más tradicional, la libertad de conciencia sería una faceta de las libertades religiosas, que incluirían a aquélla junto con la libertad de culto. La libertad de conciencia (también llamada libertad de creencias) sería el derecho de la persona a formarse sus ideas respecto de un orden trascendente y sobrenatural en general; en tanto que la libertad de culto incluiría el derecho a manifestar exteriormente esas ideas mediante los ritos y las conductas exigidas por las propias convicciones. La libertad de pensamiento, en cambio, comprendería la posibilidad de formarse ideas y creencias respecto de los diversos aspectos de la vida, no necesariamente limitado al ámbito de lo trascendente-religioso, como en el caso anterior ${ }^{30}$. La libertad de conciencia sería un derivado del derecho a la intimidad, una cuestión de volición interna, en tanto que la libertad de culto implicaría el aspecto externo de ese derecho (la manifestación pública del culto que se ha elegido).

Desde una visión más amplia (y contemporánea) la libertad de conciencia implica una modalidad de autodeterminación en toda creencia, tomando el concepto

29 Navarro Floria (2007), p. 253.

30 Bidart Campos (1988), p. 190; Bidart Campos (1998), p. 549; Padilla (1993), p. 55. 
de creencia en un sentido valorativo. La libertad de pensamiento es entonces entendida como la libertad propiamente ideológica (libertad de visión del mundo y del ser humano en relación a él $)^{31}$. La libertad de pensamiento está vinculada con las ideas; la libertad de conciencia, con la posibilidad de darse patrones valorativos para dirigir la propia vida. Para algunos, la libertad de pensamiento es el género que involucra la libertad de conciencia ${ }^{32}$; para otros, la relación es inversa ${ }^{33}$. En cualquier caso, cuando las creencias referidas por la libertad de conciencia sean creencias religiosas, estaremos en el ámbito de la libertad religiosa. En este trabajo utilizamos el concepto de libertad religiosa en este sentido.

La libertad religiosa comporta una doble dimensión ${ }^{34}$. Hay un aspecto interno, relativo a la formación, mantenimiento y cambio de las propias convicciones religiosas. Este aspecto, por referirse al fuero íntimo del individuo, resulta inmune a toda coacción estatal. Hay por otra parte un aspecto externo, que corresponde al derecho a actuar conforme a las propias creencias religiosas. La libertad de cultos referida en el artículo 14 de la Constitución argentina es, en su literalidad, una manifestación del aspecto externo: la libertad de rendir los actos propios del culto conforme a las propias convicciones. Pero el culto no agota los aspectos externos, que comprenden otros muchos ámbitos de la conducta humana que pueden responder a una convicción religiosa sin encuadrarse estrictamente en la categoría de culto. En cualquier caso, a pesar de la estrechez de la terminología del artículo 14, siempre se ha interpretado que protegía la libertad religiosa en un sentido amplio, ya sea porque la libertad de culto presupone la libertad de tener (previamente) las creencias a las que habrá de sujetarse ese culto; ya sea porque así surgía de la conjunción del artículo 14 con otros artículos de la Constitución (particularmente el ya referido artículo 19 sobre el ámbito de reserva y el 33 que dispone que los derechos enunciados no han de entenderse como negación de otros no enumerados en el texto constitucional ${ }^{35}$. Hoy esta conclusión es todavía más clara a la luz de los textos internacionales dotados de jerarquía constitucional a partir de 1994.

Tanto el aspecto interno como el externo tienen manifestaciones positivas y negativas. El aspecto positivo se refiere a la libertad de adoptar, cambiar y abandonar las propias convicciones y de ajustar la vida conforme a ellas. El aspecto negativo

\footnotetext{
31 JiMÉNEZ (2000), p. 194.

32 SAgUUÉs (1997), p. 386.

33 Jiménez (2000), p. 194.

34 Bidart Campos (1998), p. 549. CSJN: sentencia de 6 de abril de 1993, voto de los jueces Cavagna Martínez y Boggiano.

35 Bidart Campos (1988), p. 190; Bidart Campos (1998), p. 549.
} 
supone el derecho a no ser obligado a tener determinadas convicciones y de no ser obligado a actuar de acuerdo a convicciones que no se comparten, por lo que implica la prohibición de la interferencia estatal y de terceros en la intimidad de la conciencia y el derecho a no ser obligado a participar en actos que tengan un sentido religioso contra la propia voluntad ${ }^{36}$.

La libertad religiosa de la Constitución argentina protege a quienes tienen creencias religiosas y también a quienes no las tienen (ateos, agnósticos, indiferentes). A pesar de ello, no puede negarse el carácter esencialmente teísta, aunque no confesional, de la Constitución, que invoca a Dios en el preámbulo y lo vuelve a mencionar al referirse al derecho a la privacidad ${ }^{37}$.

El contenido concreto de la libertad ha sido especificado por la doctrina, la jurisprudencia y algunas leyes específicas. En general, la doctrina ${ }^{38}$ admite que, además de los actos de culto propiamente dichos, quedan amparadas por la libertad religiosa otras esferas de conducta que tienden a proteger un modo religioso de vida, como son la celebración del matrimonio religioso, la enseñanza religiosa (en particular, el derecho de los padres a decidir la orientación espiritual de sus hijos menores) o la disponibilidad de tiempo suficiente (por ejemplo, mediante autorizaciones para ausentarse del puesto de trabajo) para cumplir con los deberes religiosos. Igualmente, las organizaciones religiosas también tienen ciertos derechos, como son el de prestar la debida asistencia a sus fieles (incluso a aquellos que se encuentran en cárceles, establecimientos hospitalarios, $\mathrm{u}$ otros establecimientos públicos semejantes), de formar los ministros de su culto, de comunicarse con sus autoridades dentro y fuera del país, y de gozar de propiedades necesarias para llevar adelante su misión.

Uno de los aspectos de la libertad religiosa que más se ha desarrollado por la jurisprudencia de la Corte Suprema es el relativo al matrimonio. En un caso muy antiguo, la Corte Suprema resolvió que no vulneraba la libertad religiosa el hecho de que la antigua ley de matrimonio civil exigiera, como requisito previo a la celebración de cualquier matrimonio religioso, la celebración del matrimonio civil. Esto así ya que existe un legítimo interés del Estado en mantener una determinada forma de organización familiar y que, además, una vez cumplidos los recaudos civiles nada impedía a los contrayentes celebrar el rito matrimonial que se ajustara a sus conciencias ${ }^{39}$. Por estas mismas consideraciones no existe un deber del Estado de

\footnotetext{
36 Gelli (2005), pp. 136-137; Bidart Campos (1998), pp. 549-550.

37 Gentile (2003), p. 49.

38 Entre otros, Bidart Campos (1998), pp. 549-550.

39 CSJN: sentencia de 29 de julio de 1893.
} 
reconocer eficacia civil a los matrimonios celebrados por las confesiones religiosas: la Corte Suprema ha sostenido que no existe tal deber en relación con el matrimonio religioso católico ${ }^{40}$. Como hemos dicho, la Iglesia Católica goza de un estatus preferencial. Por lo tanto puede concluirse que si tal deber no existe en relación con el culto católico, mucho menos ha de existir en relación con otros cultos.

Resulta también interesante señalar la jurisprudencia de la Suprema Corte de Justicia que declaró la inconstitucionalidad del carácter indisoluble del vínculo matrimonial. En esta sentencia, uno de los votos concurrentes consideró que además de significar una violación del derecho constitucional a contraer matrimonio, por impedir ejercer el derecho más de una vez, el no reconocimiento del divorcio vincular en la legislación implicaba una violación de la neutralidad religiosa del Estado, por intentar imponer una forma matrimonial proveniente de la doctrina católica a la totalidad de la población ${ }^{41}$. Sin embargo, no fueron estos los argumentos de la mayoría, que encontró inconstitucional la indisolubilidad del matrimonio por ser contrario a la dignidad humana el no permitir que alguien cuyo fracaso matrimonial ha sido constatado por una sentencia judicial (por medio de un divorcio que, según la ley vigente no rompía el vínculo existente) no pueda volver a formar una familia; y porque esa solución es también contraria a la igualdad, ya que está en el espíritu constitucional el brindar a quienes son víctimas, aún de sus propios desaciertos, la posibilidad de recomponer su existencia y esta posibilidad que se acuerda a algunos no se les puede negar a los divorciados ${ }^{42}$.

Paralelamente, así como se planteó si el no reconocimiento del divorcio vincular en la legislación argentina podía suponer una situación de inconstitucionalidad, también se planteó la pregunta inversa: frente a un régimen jurídico de matrimonio disoluble en vida de los cónyuges, ‘hay violación a derechos constitucionales en la prohibición de renunciar anticipadamente al divorcio vincular impuesta por la ley civil? La respuesta del máximo tribunal argentino fue negativa: consideró que el hecho de que una norma del Código Civil prohibiera renunciar anticipadamente a la posibilidad de pedir el divorcio vincular en nada afectaba la conciencia de los contrayentes, porque nada impedía que ellos se abstuvieran, durante toda su

\footnotetext{
40 CSJN: sentencia de 12 de agosto de 1982.

${ }^{41}$ CSJN: sentencia de 27 de noviembre de 1986, voto del juez Bacqué.

${ }^{42}$ CSJN: sentencia de 27 de noviembre de 1986, voto de la mayoría. Otro voto concurrente (juez Petracchi) encontró agravios constitucionales respecto del derecho a contraer matrimonio, pero no respecto de la neutralidad religiosa del Estado. Los votos en disidencia negaron que la indisolubilidad del vínculo matrimonial implicara violación del derecho a casarse constitucionalmente protegido, o significara una imposición de las reglas de un culto determinado a la totalidad de la población (voto del juez Severo Caballero y voto del juez Belluscio).
} 
vida, de pedir el divorcio, y cumplieran de este modo el mandato de su confesión ${ }^{43}$. Un voto concurrente agregó que, si se reconociera el derecho a celebrar un matrimonio indisoluble, y el contrayente luego cambiara sus creencias y solicitara que se anulara la promesa de indisolubilidad, se llegaría al absurdo de tener que acordar esta última petición, habiendo antes acordado la posibilidad de pactar la indisolubilidad ${ }^{44}$. Un solo voto disidente encuadró el caso como una objeción de conciencia e hizo lugar al reclamo ${ }^{45}$.

La libertad religiosa ha derivado en algunas políticas de reconocimiento de la identidad de grupos minoritarios, mediante mecanismos de acción positiva y otras políticas públicas. Sin embargo, se trata de casos limitados y las tendencias igualitaristas (con algunas dosis de asimilacionismo) presentes en la historia argentina todavía persisten.

Entre estas políticas especiales hay que situar la que surge del texto constitucional (resultante de la reforma de 1994) que establece, entre las atribuciones del Congreso, la de reconocer la preexistencia étnica y cultural de los pueblos aborígenes argentinos ${ }^{46}$. La situación es difusa: no se otorga ninguna preferencia puntual y concreta a estos grupos ni a sus creencias religiosas (que por otra parte no son expresamente mencionadas, aunque se habla del respeto a su identidad que, obviamente, incluye los aspectos espirituales), pero resulta claro que ellos son merecedores de una atención particular. En los hechos, las políticas de reconocimiento son limitadas. Se han establecido organismos del Estado nacional (por ejemplo, el Instituto Nacional de Asuntos Indígenas) y de los gobiernos provinciales, pero en general orientados a políticas de asistencia social de las comunidades aborígenes. Por otra parte, entre los objetivos de la Ley Nacional de Educación se encuentran el asegurar a los pueblos indígenas el respeto a su lengua y a su identidad cultural, promoviendo la valoración de la multiculturalidad en la formación de todos/as los/as educandos/as ${ }^{47}$. Pero los

${ }^{43}$ CSJN: sentencia de 13 de agosto de 1998.

${ }^{44}$ CSJN: sentencia de 13 de agosto de 1998, voto del juez Vázquez.

45 CSJN: sentencia de 13 de agosto de 1998, voto del juez Boggiano.

46 Según el artículo 75 inciso 17 de la Constitución de la Nación Argentina, corresponde al Congreso Nacional: "Reconocer la preexistencia étnica y cultural de los pueblos indígenas argentinos. Garantizar el respeto a su identidad y el derecho a una educación bilingüe e intercultural; reconocer la personería jurídica de sus comunidades, y la posesión y propiedad comunitarias de las tierras que tradicionalmente ocupan; y regular la entrega de otras aptas y suficientes para el desarrollo humano; ninguna de ellas será enajenable, transmisible, ni susceptible de gravámenes o embargos. Asegurar su participación en la gestión referida a sus recursos naturales y a los demás intereses que los afectan. Las provincias pueden ejercer concurrentemente estas atribuciones".

${ }^{47}$ Artículo 11 inciso ñ, ley 26206 de 2006. 
porcentajes de miembros de comunidades aborígenes que, estando escolarizados, recibe educación bilingüe son muy bajos. Ha habido también avances en algunas cuestiones puntuales, como el otorgamiento de tierras a grupos aborígenes (la posesión de la tierra, como se sabe, es muy relevante en las tradiciones espirituales de muchas comunidades) y la existencia de un Consejo de Participación Indígena (que ejerce una representación de las comunidades ante el Estado Nacional).

En otro orden de cosas, siempre en relación con las políticas diferenciadas dirigidas a los grupos religiosos minoritarios, hay que mencionar algunas normas legales que disponen reglas excepcionales en virtud de la pertenencia religiosa de los destinatarios, tendientes a facilitar la práctica de la propia religión. Así, dos leyes establecen como no laborables para los trabajadores de religión judía determinadas festividades ${ }^{48}$. Resoluciones administrativas de diferentes organismos educativos suelen permitir la exención de exámenes en día sábado para judíos y adventistas del séptimo día.

Vamos a mencionar por último que la libertad religiosa del texto constitucional también puede servir como criterio de interpretación de la normativa infraconstitucional. Así, la Corte Suprema decidió un caso en el que se planteaba cuál era la interpretación adecuada que debía darse al precepto legal que reconocía una excepción al servicio militar obligatorio a favor de los seminaristas y ministros de todas las religiones. Estaba claro que los ministros de todas las religiones estaban exentos, pero la duda era si el vocablo seminarista debía entenderse en su sentido histórico y tradicional (es decir, como seminarista católico) o en el sentido más amplio correspondiente a toda persona que cursa estudios religiosos con la finalidad de ordenarse como ministro de un culto. La Corte incluyó en los argumentos a favor de la interpretación amplia la libertad religiosa ${ }^{49}$.

\subsection{Limites del derecho}

La Corte Suprema de Justicia, en su jurisprudencia, no ha elaborado una doctrina clara acerca de cuáles son los límites a la libertad religiosa que han de ser aceptados para tornar compatible su ejercicio con el de los demás derechos del sistema constitucional. Ha habido, es cierto, algunas indicaciones generales, incluidas en sentencias sobre la objeción de conciencia (tema que abordamos en la sección siguiente).

\footnotetext{
${ }^{48}$ Leyes 24571 de 1995 y 24747 de 1997. Las festividades son Año Nuevo (Rosh Hashanah), Día del Perdón (Yom Kippur) y Pascua (Pesach) para los judíos; y Año Nuevo (Hégira), el día siguiente al fin del Ramadán (Eid al-Fitr) y el día del Sacrificio (Eid al-Adha) para los musulmanes. Estas leyes están complementadas por la ley 25151 de 1999 sobre paga de los días festivos de trabajadores judíos y musulmanes. Ver NAVARRO FLORIA (2005), pp. 310-312.

49 CSJN: sentencia de 23 de septiembre de 1966.
} 
La definición general de tales límites puede encontrarse en la doctrina de los autores. En términos generales, puede decirse que tales límites son los indispensables para el mantenimiento de la armonía entre la libertad religiosa y otros valores e intereses constitucionalmente protegidos. Para el mantenimiento de este equilibrio, la libertad religiosa habrá de sufrir restricciones que la tornen compatible con esos otros valores e intereses constitucionales. En cualquier caso, un primer elemento a tener en cuenta es que la limitación de la libertad religiosa ha de evaluarse con carácter restrictivo. Esta limitación debe ser una medida de carácter excepcional a la que sólo se recurra cuando no exista otra forma de satisfacer los intereses sociales ${ }^{50}$. El carácter restrictivo con el que puede procederse a limitar la libertad está en relación con el pluralismo religioso propio de un Estado liberal: la relación del individuo con su dios, en principio, no es una cuestión que interese al Estado ${ }^{51}$.

Por otra parte, cuando la libertad religiosa pueda oponerse a un deber constitucionalmente establecido, se debe favorecer la interpretación que mejor logre la armonización de ambos, y no oponer unos a otros de modo que se destruyan recíprocamente ${ }^{52}$. Por el contrario, se debe estudiar el espíritu que ha dado vida a unos y otros, entendiendo cada una de las disposiciones constitucionales a la luz de todas las demás, y respetando así la unidad sistemática de la Carta Fundamental ${ }^{53}$.

Un primer requisito necesario para legitimar la restricción a la libertad religiosa, común a las restricciones de derechos en general por expresa disposición constitucional, es el del rango legal de la norma que establece la restricción. En efecto, el artículo 14 de la Constitución subordina los derechos que en él aparecen reconocidos a las leyes que reglamenten su ejercicio. Así, la costumbre no es base suficiente para justificar una restricción al derecho, como lo advirtió la Corte Suprema de Justicia cuando resolvió que existe una violación a la libertad religiosa si una sentencia de un tribunal inferior, reconociendo que la ley no contiene ninguna disposición sobre los nombres que puede darse a las personas, se funda en la costumbre para prohibir que se dé a un niño un nombre en idioma extranjero que no pertenece al santoral católico ${ }^{54}$.

La reglamentación legal debe ser, además, razonable. La razonabilidad de la reglamentación exige que las normas reglamentarias estén justificadas por los hechos

\footnotetext{
50 Gelli (2005), p. 157.

51 VANOSSI (1981), p. 592.

52 CSJN: sentencia de 14 de abril de 1989.

53 CSJN: sentencia de 9 de agosto de 2005, voto de la jueza Highton de Nolasco.

${ }^{54}$ CSJN: sentencia de 1945 (en la base de datos del alto tribunal sólo figura el año, pero no la fecha exacta de la sentencia).
} 
y las circunstancias que les han dado origen, y por la necesidad de salvaguardar el interés público comprometido ${ }^{55}$.

Finalmente la doctrina enfatiza la necesidad de que se respeten dos criterios: el de finalidad legítima y el de proporcionalidad. Así, la finalidad que justifica la restricción de la libertad religiosa ha de estar vinculada a la protección del orden y la moral públicos, o de los derechos de terceros ${ }^{56}$. La Corte Suprema se ha referido a las finalidades legítimas al reconocer que la libertad religiosa encuentra sus límites en las exigencias razonables del justo orden público ${ }^{57}$. Igualmente se ha puesto en relieve el carácter restrictivo con el que ha de interpretarse el concepto de orden público, ya que para la Corte Suprema la libertad de una persona de tomar las decisiones fundamentales en este campo, puede ser válidamente limitada en aquellos casos en que exista algún interés público relevante en juego, y siempre que la restricción al derecho individual sea la única forma de tutelar dicho interés ${ }^{8}$. Así, el libre juego de la autonomía de la voluntad tiene su campo en todo aquello que no esté vedado por la reserva del orden público ${ }^{59}$.

Por otra parte, se debe evaluar estrictamente la proporcionalidad entre la finalidad perseguida y el medio elegido ${ }^{60}$. Como ha dicho la Corte Suprema, se trata de buscar el equilibrio entre el interés privado y el público, protegiendo este último en forma adecuada a los fines que se procura alcanzar ${ }^{61}$.

\subsection{Libertad religiosa e igualdad}

El principio constitucional de igualdad se manifiesta doblemente en materia de libertad religiosa. Existe, por un lado, un derecho al goce igualitario de esta libertad. Existe, por otro lado, el derecho a no ser discriminado por motivos religiosos. Ambas dimensiones son una derivación del principio constitucional de igualdad que aparece en el artículo 16 del Texto Fundamental. En los párrafos que siguen veremos con más detalle el segundo aspecto mencionado, que ha recibido un importante tratamiento en normas de rango legal.

55 CSJN: sentencia de 14 de abril de 1989. CSJN: sentencia de 9 de agosto de 2005, voto de la jueza Highton de Nolasco.

56 Gelli (2005), p. 137-138.

${ }^{57}$ CSJN: sentencia de 6 de abril de 1993, voto de los jueces Cavagna Martínez y Boggiano. CSJN: sentencia de 9 de agosto de 2005, voto de la jueza Highton de Nolasco.

${ }^{58}$ CSJN: sentencia de 6 de abril de 1993, voto de los jueces Belluscio y Petracchi.

59 VANOSSI (1981), p. 592.

${ }^{60}$ Gelli (2005), p.137-138.

${ }^{61}$ CSJN: sentencia de 6 de abril de 1993, voto de los jueces Cavagna Martínez y Boggiano. CSJN: sentencia de 9 de agosto de 2005, voto de la jueza Highton de Nolasco. 
El derecho a la no discriminación por razones religiosas ha sido reglamentado en distintas normas jurídicas. La ley relativa a las medidas contra actos discriminatorios en el ejercicio de derechos y garantías constitucionales establece la prohibición de discriminación respecto del ejercicio de derechos constitucionales, y prevé indemnizaciones para la reparación del daño moral y material en caso de que tales actos discriminatorios tengan lugar ${ }^{62}$. Igualmente, se especifica que se tendrán particularmente en cuenta, como casos de discriminación, los actos basados en criterios de religión $n^{63}$. Además, se establecen mecanismos de tutela penal frente a la discriminación, con expresa mención de la discriminación religiosa ${ }^{64}$. La protección penal aparece también en el Código Penal, que establece un tipo agravado de homicidio cuando éste se produce por odio religioso y agrava igualmente la privación ilegítima de libertad cuando es cometida con fines religiosos ${ }^{65}$.

Las prohibiciones de discriminar por motivos religiosos aparecen igualmente en otros textos legales: ley de nacionalidad ${ }^{66}$, ley de partidos políticos ${ }^{67}$, leyes de trabajo y de sindicatos ${ }^{68}$, régimen de la administración pública ${ }^{69}$, régimen peni-

\footnotetext{
${ }^{62}$ Artículo 1, párrafo 1, ley 23592 de 1998: "Quien arbitrariamente impida, obstruya, restrinja o de algún modo menoscabe el pleno ejercicio sobre bases igualitarias de los derechos y garantías fundamentales reconocidos en la Constitución Nacional, será obligado, a pedido del damnificado, a dejar sin efecto el acto discriminatorio o cesar en su realización y a reparar el daño moral y material ocasionados".
}

${ }^{63}$ Artículo 1, párrafo 2, ley 23592 de 1998.

${ }^{64}$ La misma ley eleva en un tercio el mínimo y en un medio el máximo de la escala penal de todo delito cuando el mismo sea cometido por persecución u odio a una religión o con el objeto de destruir en todo o en parte a un grupo religioso, sin que en ningún caso se pueda del máximo legal de la especie de pena de que se trate (artículo 2, ley 23592 de 1998). También se reprime con prisión, de un mes a tres años, a los que participaren en una organización o realizaren propaganda basados en ideas o teorías de superioridad de un grupo de personas de determinada religión, que tengan por objeto la justificación o promoción de la discriminación religiosa en cualquier forma, o los que por cualquier medio alentaren o iniciaren a la persecución o el odio contra una persona o grupos de personas a causa de su religión (artículo 3, ley 23592 de 1998).

${ }^{65}$ Artículos 80 inciso 4 y 142 inciso 1 respectivamente del Código Penal.

${ }^{66}$ La ley 346 de 1869 prohíbe negar el otorgamiento de nacionalidad por razones religiosas (artículo 11).

${ }^{67}$ La ley 23298 de 1985 de partidos políticos prohíbe que los nombres de los mismos contengan expresiones que exterioricen antagonismos religiosos o conduzcan a provocarlos (artículo 16).

${ }^{68}$ El régimen laboral de la ley 20744 de 1974 prohíbe cualquier discriminación entre los trabajadores por motivos de religión (artículo 17), debiendo dispensar el empleador a todos los trabajadores igualdad de trato en igualdad de condiciones, sin discriminaciones arbitrarias por motivos de religión (artículo 81). La ley 25212 de 2002 del Pacto Federal del Trabajo tipifica como infracción muy grave del empleador cualquier acto que implique discriminación en el empleo o la ocupación por motivos de religión (artículo 4 inciso a). La ley 23551 de 1988 de sindicatos prohíbe las discriminaciones por razones de credo (artículo 7).

${ }^{69}$ La ley 25164 de 1999 de empleo público prohíbe al personal de la administración federal desarrollar toda acción u omisión que suponga discriminación por razón de religión (artículo 24 inciso h). 
tenciario ${ }^{70}$, etc. Además, el derecho a no ser discriminados por motivos religiosos ha sido reconocido por el máximo tribunal de justicia argentino, afirmando que las creencias religiosas de las personas no pueden ser causa de restricción de otros derechos, mientras no se manifiesten en actos prohibidos o causen daños a terceros ${ }^{71}$.

Dado que las normas legislativas son dictadas respondiendo a la voluntad de las mayorías, es posible que su contenido choque con las convicciones religiosas de grupos minoritarios. Para salvar el respeto a la libertad religiosa asegurando su goce en condiciones de igualdad, puede ser necesario en algunos casos incluir excepciones en las normas de carácter general que permitan el acomodamiento de las prácticas de los grupos minoritarios. Esta idea aparece en la jurisprudencia de la Corte Suprema ${ }^{72}$. Ya hemos visto ciertas normas especiales dirigidas a proteger la libertad religiosa de los miembros de grupos minoritarios. En el apartado siguiente nos referiremos a la objeción de conciencia.

\section{OBJECIÓN DE CONCIENCIA}

\subsection{Delimitación conceptual en el derecho constitucional argentino}

Como derivación de la libertad de conciencia aparece en el horizonte jurídico el concepto de objeción de conciencia. La misma puede ser entendida como la pretensión de eximirse del cumplimiento de un deber jurídico con el argumento de que el cumplimiento de ese deber resulta repugnante a las creencias del objetor. Se trata de manifestar un reparo en la realización u omisión de conductas que pueden hacer peligrar las íntimas convicciones y las creencias personales. El objetor busca primariamente resolver la íntima antinomia de su conciencia personal con lo establecido por las normas: sus propósitos son meramente defensivos. Éste parece ser el concepto de objeción de conciencia dominante en la doctrina constitucional argentina ${ }^{73}$, coincidente, por otra parte, con el concepto dado por la Corte Suprema de Justicia. Esta última ha entendido la objeción de conciencia como el derecho a no cumplir una norma u orden de la autoridad que violente las convicciones intimas

\footnotetext{
${ }^{70}$ La ley 24660 de 1996 prohíbe las discriminaciones religiosas en los casos de privación de libertad. Reconoce el derecho de los detenidos a la libertad de conciencia y de religión, de ser asistidos por representantes de sus religiones en cuanto estén registradas en el Registro Nacional de Religiones y en la medida de lo posible, manifestar sus religiones o creencias.

${ }^{71}$ CSJN: sentencia de 26 de junio de 1980; CSJN: sentencia de 23 de septiembre de 1966.

72 CSJN: sentencia de 9 de agosto de 2005, voto de la jueza Highton de Nolasco.

73 Quiroga Lavié, Benedetti y Cenicacelaya (2009), p. 222; Bermúdez (2007), p. 99. Sobre la objeción de conciencia en general ver NAVARro Floria (2004).
} 
de una persona, siempre que dicho incumplimiento no afecte significativamente los derechos de terceros ni otros aspectos del bien común ${ }^{74}$.

Este concepto de objeción de conciencia aparece en la doctrina constitucional junto con la idea de que, para obtener la protección que el Estado debe brindar a la libertad de conciencia, el objetor tiene la carga de probar la sinceridad de las convicciones que invoca. El ejercicio de la objeción de conciencia debe estar exento de cualquier elemento relacionado con el oportunismo, o el deseo de evitar penalidades o los riesgos que supone el cumplimiento de un deber cívico. Su justificación debe encontrarse en rigurosas razones religiosas, éticas o humanitarias ${ }^{75}$.

La objeción de conciencia es clasificada dentro de un esquema tripartito de modos de excepcionar el cumplimiento de las reglas que el ordenamiento jurídico impone, y que incluye, junto con la objeción que estudiamos, la desobediencia revolucionaria y la desobediencia civil. La desobediencia revolucionaria tiene lugar cuando se busca, mediante la desobediencia al derecho, lograr un cambio de gobierno o de disposiciones constitucionales globalmente considerados. La desobediencia civil, en cambio, sólo busca cambiar una disposición concreta del ordenamiento jurídico o, más simplemente, realizar una manifestación de protesta pública. A diferencia de estos dos casos, quien invoca la objeción de conciencia se niega a obedecer al derecho porque cree que le está moralmente prohibido hacerlo ${ }^{76}$. Es una acción con la que el agente busca proteger su conciencia de interferencias por parte de la autoridad pública, sin que el objetor pretenda promover o cambiar política alguna ${ }^{77}$. En este sentido, la objeción de conciencia es una forma de desobediencia de la ley o de excepcionarse al cumplimiento de la ley asimilable por el sistema democrático, en tanto es pacífica y guarda lealtad con el mismo ${ }^{78}$.

¿En qué casos puede invocarse con éxito la objeción de conciencia? Aquí se debe realizar una distinción. En primer lugar, es posible que la misma norma que establece el deber jurídico cuyo cumplimiento se pretende eludir, u otra norma paralela, prevean la posibilidad de invocar el instituto en cuestión. En este caso, mientras estén reunidos los extremos que la misma norma exige, es indudable que puede invocarse. Ahora bien, cuando no existe una norma expresa que prevea la excepción respectiva, la cuestión resulta más difícil, ya que habrá que argumentar que la excepción de conciencia está implícita en las normas

74 CSJN: sentencia de 9 de agosto de 2005, voto de la jueza Highton de Nolasco.

75 Albanese (1988), p. 800.

76 JiMÉNEZ (2000), p. 199.

77 Jiménez (2000), p. 201.

78 Dalla Via (1989), p. 387. 
constitucionales que protegen la libertad de conciencia (y la objeción de conciencia por motivos religiosos en las normas constitucionales que protegen la libertad religiosa). Como veremos en los párrafos siguientes, esto es precisamente lo que ha hecho la Corte Suprema de Justicia argentina en su jurisprudencia constitucional, delimitando cuándo es posible invocar la objeción de conciencia y cuáles son sus límites.

\subsection{La objeción de conciencia en el derecho constitucional positivo argentino}

La jurisprudencia de la Corte Suprema de Justicia argentina ha derivado, de las normas constitucionales que protegen la libertad religiosa, un derecho implícito a obtener, bajo ciertas condiciones, una excepción a las reglas del derecho común que hagan posible su compatibilidad con las exigencias de las propias convicciones. Entre las normas constitucionales involucradas está el ya mencionado artículo 14, y también el artículo 19. La libertad religiosa está vinculada a la primera parte del art. 19 que, como hemos visto, consagra el principio de reserva y el derecho a la intimidad. Los actos privados deben ser respetados aunque incomoden a algunos, reciban reproche social o no sean concordantes con las pautas de comportamiento de la mayoría ${ }^{79}$ ya que el límite de tales actos se encuentra sólo en el orden y la moral públicos, y el perjuicio a terceros.

Veamos ahora los hitos fundamentales en la jurisprudencia del máximo tribunal argentino sobre la materia que nos ocupa. Existe un caso antiguo, de fines de la década del ' 40 del pasado siglo, relativo a las posibles excepciones a la obligación de prestar juramento para obtener determinados beneficios o acceder a determinados cargos. La Corte se ocupó de la cuestión en el caso Agüero ${ }^{80}$. El actor se había graduado de procurador en la Universidad Nacional de Córdoba y había pedido que se le eximiera de prestar el juramento de práctica en el acto de la entrega de su diploma por ser ello incompatible con sus convicciones religiosas, pues pertenecía la Iglesia Evangélica Bautista. Invocó los artículos 14 y 19 de la Constitución Nacional y el inciso 2 del artículo 531 del Código Civil (la entrega del diploma estaría sometida a la condición de mudar o no mudar de religión, condición que resulta prohibida por dicho cuerpo legal). La Universidad replicó diciendo que ella extiende su título a quienes cumplan con las condiciones reglamentarias, entre las cuales se encuentra la del juramento al serles entregado, y que no se coartan las libertades constitucionales ni es aplicable el dispositivo civil

79 CSJN: sentencia de 9 de agosto de 2005, voto de la jueza Highton de Nolasco.

${ }^{80}$ CSJN: sentencia de 1949 (en la base de datos del alto tribunal sólo figura el año, pero no la fecha exacta de la sentencia). 
aludido, porque a nadie se obliga a cambiar de religión cuando ingresa a cursar estudios a la institución.

La Corte Suprema rechazó la objeción de conciencia en este caso. Consideró que no corresponde la invocación del artículo 19, porque este precepto protege las acciones privadas que no afectan el orden público, en tanto que el juramento obligatorio estaría impuesto por razones de orden público. Igualmente consideró que no había violación a la libertad religiosa del artículo 14 y esto último por dos razones. Por un lado, porque la Corte considera que el juramento no violenta la conciencia del interesado (en contra, en este punto, de lo que el propio interesado sostiene) ya que el demandante no se opone al contenido del juramento, sino a su forma, y para la Corte la forma del juramento no vincula la conciencia de quien lo presta, sino de aquel ante quien se presta tal solemnidad. Por otro lado, porque la propia Constitución exige prestar juramento como requisito para acceder a ciertas funciones públicas.

La doctrina más reciente cuestiona esta solución de la Corte ${ }^{81}$. La Corte parece haber realizado un análisis superficial de las cuestiones constitucionales en juego, sin valorar en toda su extensión la libertad religiosa y sin advertir que podrían obtenerse los mismos efectos buscados por el régimen universitario mediante otros mecanismos menos lesivos de la conciencia individual (por ejemplo, el reemplazo del juramento por una promesa solemne o equivalente como lo proponía el señor Agüero). De todos modos, a la luz de la jurisprudencia más reciente (de la que hablaremos en seguida) cabe pensar que si esta cuestión se suscitase nuevamente, la solución sería distinta a la dada en el caso que examinamos.

El ámbito clásico de la objeción de conciencia es del servicio militar. La posibilidad de objetar no estaba prevista en las normas legales relativas a la prestación del servicio, de modo que la Corte Suprema fue llamada a clarificar la cuestión. La objeción de conciencia para eximirse del servicio militar fue, en un primer momento, rechazada por la Corte en el caso Lopardo ${ }^{82}$ y luego en Falcón ${ }^{83}$, en este último caso, remitiendo a los fundamentos del caso anterior. Allí señala la Corte que no es aceptable la causal de exclusión de culpabilidad alegada contra la sentencia de tribunal militar que condenó por el delito de insubordinación al ciudadano que se negó a prestar el servicio militar, bajo pretexto de estarle prohibido por su confesión religiosa (era Testigo de Jehová), ya que no demostró estar incluido en la condición eximente prevista en la ley respectiva de ser ministro,

${ }^{81}$ Jiménez (2000), p. 198; Bidart Campos (1998), p. 550 ; Bidart Campos (1988), p. 191.

${ }^{82}$ CSJN: sentencia de 26 de octubre de 1982.

${ }^{83}$ CSJN: sentencia de 21 de junio de 1983. 
novicio o religioso de un culto reconocido. En lo que nos interesa, resolvió que no se puede interpretar que el derecho a la libertad religiosa del artículo 14 y la intimidad protegida en el 19, estén en conflicto con el deber que impone el artículo 21 de la Constitución (relativo al servicio militar) o con el objetivo de proveer a la defensa común que aparece en el preámbulo constitucional. En efecto, el artículo 21 de la Constitución establece que todo ciudadano argentino está obligado a armarse en defensa de la Patria y de la Constitución, mientras que el preámbulo de la Constitución reconoce que uno de los objetivos de ésta es el de proveer a la defensa común. Así las cosas, en la perspectiva de la Corte no podría hablarse de un derecho constitucional vulnerado, porque esto implicaría aceptar que la vulneración proviene de otra norma del propio texto constitucional. Por otra parte, aunque se invocara la libertad religiosa habría que recordar que ésta halla su límite en las exigencias razonables del justo orden público, del bien común de la sociedad y en la protección de la existencia y de los legítimos derechos de la Nación, todos estos extremos que estarían en juego en relación con la prestación militar. Igualmente se reiteró aquí el argumento de que el artículo 19 no es invocable precisamente porque en la especie está en juego el orden público.

También esta posición restrictiva de la Corte es cuestionada por la doctrina, que habla de la existencia en el caso de un control de razonabilidad débil y genérico, sin que la Corte se haya detenido a examinar de qué modo puede cumplirse el fin de proteger a la Nación por medios menos lesivos ${ }^{84}$. Igualmente, aunque hay que reconocer que los derechos individuales no son absolutos, tampoco lo son los deberes (las propias leyes que contenían causales de exención del servicio militar por motivos razonables daban prueba de ello), de manera que se imponía realizar en el caso un equilibrio entre los valores protegidos, que no tenía porqué llevar a una supremacía automática a favor de la norma que impone el deber por sobre aquella que reconoce el derecho ${ }^{85}$. Al interpretar el contenido de las sentencias comentadas, en perspectiva histórica, no puede desconocerse el hecho de que ambas fueron dictadas bajo el imperio de la última dictadura militar.

El máximo tribunal argentino cambió la orientación de su jurisprudencia en el caso Portillo ${ }^{86}$, dictado ya en el periodo democrático. En este caso se reconoció por primera vez rango constitucional a la objeción de conciencia. Resulta interesante señalar que se trataba de alguien que profesaba la religión católica (y no un seguidor del grupo de Testigos de Jehová, que tradicionalmente han objetado la

${ }^{84}$ Gelli (2005), p. 138.

85 Bidart Campos (1983), p. 736; Gelli (2005), p. 138.

${ }^{86}$ CSJN: sentencia de 14 de abril de 1983. 
institución militar). El actor consideraba tal obligación como contraria al quinto mandamiento (no matar) y señalaba que creía poder servir a la Patria de muchas otras maneras cumpliendo un servicio civil (la prestación sustitutoria del servicio militar no estaba legalmente prevista). El Alto Tribunal advirtió la tensión entre derechos y obligaciones consagrados en las normas constitucionales de los artículos 14 y 21 . Surgía entonces la necesidad de encontrar una interpretación que armonizara las normas en pugna. Ahora bien, dado que el incumplimiento de la estricta obligación militar no conllevaba un peligro grave o inminente a los intereses del Estado, toda vez que el servicio que se exigía debía ser cumplido en tiempos de paz, se debía buscar alternativas que permitieran al sujeto obligado cumplir con sus deberes sin violentar sus convicciones.

En un giro radical respecto de sus propios precedentes, la Corte Suprema interpretó en el caso que de la combinación de los artículos 14 y 19 de la Constitución surgía un ámbito protegido de la conciencia del ciudadano en el que el Estado no podía intervenir. Sin embargo, esto no significaba sin más eximirse totalmente del deber de contribuir a la defensa de la Nación, ya que tal obligación es una convocatoria a la defensa de las libertades e instituciones reconocidas en la Constitución y resultaría un sinsentido invocar una libertad constitucional para eximirse del deber de proteger a la propia Constitución. Lo que sí surge del sistema de derechos constitucionales, interpretó la Corte, es una potestad de cumplir con ese deber pero siendo eximido del uso de armas.

Algún sector doctrinal criticó este cambio jurisprudencial de la Corte aduciendo que se hizo prevalecer el interés individual, sin tener en cuenta que éste halla sus límites en las razonables exigencias del orden público y el bien común ${ }^{87}$. De que se ha hecho prevalecer un interés individual parece no haber duda: ésa es precisamente la solución que la Corte encontró implícita en una Constitución de bases liberales como la argentina. Ahora bien, no parece ser cierto que ese interés personal avasalle las razonadas exigencias del orden público, ya que no está muy claro cómo se podían ver afectadas las necesidades de la defensa nacional por el hecho de que unos pocos pretendieran eximirse del uso de armas al cumplir una carga pública, por razones de libertad de conciencia, además de la crítica que podría hacerse (aunque esto va más allá de la estricta interpretación constitucional) de la utilidad de la figura misma del servicio militar obligatorio para satisfacer las necesidades de la defensa nacional en las puertas del siglo XXI, cuando fue dictada la sentencia ${ }^{88}$.

87 ÁlVarez (1989), p. 381.

${ }^{88}$ Herrendorf (1989), p. 371. 
En la actualidad la temática de la objeción de conciencia al servicio militar ha devenido abstracta, ya que desde la aprobación de la ley sobre servicio militar voluntario ha sido abolida la prestación militar obligatoria ${ }^{89}$.

Permanece sin embargo el interés de la objeción de conciencia en otros ámbitos, como es el electoral. Como es sabido, el sufragio es obligatorio en Argentina, lo que puede llevar a una contradicción con los preceptos de aquellas religiones que impiden votar a sus prosélitos. Existe jurisprudencia de la Cámara Nacional Electoral que rechazó la posibilidad de invocar en tales casos la objeción de conciencia ${ }^{90}$. Se trataba de un caso en el que se planteaba la inconstitucionalidad del voto obligatorio, por ser contrario a la libertad de cultos ${ }^{91}$. En el caso particular, los recurrentes sostenían que su credo no les permitía participar en la elección de las autoridades porque sólo Dios puede establecerlas. La Cámara desestimó el recurso, por razones de tipo procesal, aunque decidió de todos modos pronunciarse sobre el fondo con una finalidad puramente ilustrativa (y por ello abstracta). Basándose en los antecedentes de la Corte Suprema que habían declarado la constitucionalidad del voto obligatorio (en términos generales, es decir, fuera de un caso de conciencia) ${ }^{92}$, y en la propia consideración de que la obligatoriedad del sufragio no afecta la libertad religiosa, la Cámara Electoral rechazó la posibilidad de invocar la objeción de conciencia.

A diferencia de lo que sucede con otras formas de objeción de conciencia, no parece que ésta tenga el favor de la doctrina, que se pronuncia en sentido coincidente con la sentencia de la Cámara Electoral ${ }^{93}$. Para esta opinión, el criterio se vería reforzado con la incorporación expresa del carácter obligatorio del voto en el texto constitucional después de la reforma de $1994^{94}$. En cualquier caso, cabe preguntarse si no sucedería aquí lo mismo que, en su momento, sucedió con el servicio militar: una institución constitucionalmente reconocida, a la que se hacía una excepción por aplicación de otra norma constitucional.

Vamos a analizar ahora dos casos, en los que la excepción de conciencia se pedía en relación con la obligación impuesta a los alumnos de las escuelas públicas de

\footnotetext{
${ }^{89}$ Ley 24429 de 1994.

90 Cámara Nacional Electoral: sentencia de 21 de agosto de 1991.

$91 \mathrm{Al}$ momento de resolverse el caso, el carácter obligatorio del sufragio surgía sólo de una norma legal. Desde la reforma de 1994, el carácter obligatorio del sufragio tiene rango constitucional (artículo 37 de la Constitución de la Nación Argentina).

${ }_{92}$ CSJN: sentencia de 1933 (en la base de datos del alto tribunal sólo figura el año, pero no la fecha exacta de la sentencia).

93 Bidart Campos (1991), p. 556; Jiménez (2000), p. 198.

94 JiMÉNEZ (2000), p. 198.
} 
guardar reverencia a los símbolos nacionales (participar en la ceremonia diaria de izado de la bandera, cantar el himno nacional en determinados actos solemnes, etc.). La Corte Suprema se pronunció en un caso $\left(\right.$ Barros $\left.^{95}\right)$ respecto de la expulsión de una escuela de alumnos de siete y ocho años cuyos padres pertenecían a la comunidad religiosa de los Testigos de Jehová por entender que no reverenciaban los símbolos patrios, los próceres y las fechas nacionales en la forma establecida por una resolución del Consejo Nacional de Educación. La Corte resolvió que la decisión adolecía de arbitrariedad manifiesta y se oponía al derecho constitucional de aprender. Por otra parte, si bien el recurrente había planteado que la decisión, además de las tachas antes mencionadas, se oponía a la libertad de conciencia y de cultos, este argumento no fue tenido en cuenta por el Alto Tribunal al considerar que con los fundamentos anteriores era suficiente para resolver la cuestión a favor del peticionante.

En sentido semejante existen también antecedentes de la Corte Suprema de la provincia de Buenos Aires ${ }^{96}$. Se objetaba la expulsión de un establecimiento de educación pública de un grupo de alumnos pertenecientes al culto Testigos de Jehová por no cumplir la obligación de reverenciar los símbolos patrios. La Corte declaró que la resolución del Ministerio de Educación que obligaba a los directores de tales establecimientos a aplicar la medida de expulsión resultaba contraria a la Constitución provincial. Sin embargo, el argumento utilizado por el tribunal fue que siendo, conforme a la Constitución provincial, uno de los fines principales de la educación común la formación del carácter de los niños en el culto de las instituciones patrias, la medida expulsiva que prevé la resolución ministerial impugnada carece de razonabilidad, porque la expulsión no se adecua a la consecución del fin propuesto. Por otra parte, la sanción no se compadece con la gradualidad que debe ser propia de las sanciones disciplinarias. La Corte rechazó expresamente el argumento fundado en la libertad religiosa, ya que el grupo de los Testigos de Jehová estaba ilegalizado al momento de dictarse la sentencia.

El rechazo de la legitimidad de la objeción en estos casos (aunque la sentencia haya sido finalmente favorable al reclamante por otros motivos) es cuestionable ya que resulta razonable que el Estado exija respeto a sus símbolos, pero éste puede satisfacerse con la simple omisión de injuria o menosprecio. No es necesario requerir una conducta activa, sino que es suficiente con no ultrajar. Así, quien

\footnotetext{
${ }^{95}$ CSJN: sentencia de 6 de marzo de 1979.

96 Suprema Corte de Justicia de la Provincia de Buenos Aires: sentencia de 2 de septiembre de 1980. La norma que prohíbe la actividad del grupo Testigos de Jehová, y a la que hace referencia el fallo, se encuentra hoy derogada.
} 
en una actitud pasiva y por motivos religiosos se abstiene de cantar el himno, de ponerse una escarapela en un día de fiesta nacional, de saludar la bandera, usa lícitamente de su derecho o libertad de no expresarse, su derecho al silencio ${ }^{97}$. Este fue precisamente el sentido de un voto disidente en un tercer caso relativo a la obligación de reverenciar los símbolos patrios. La Asociación de los Testigos de Jehová planteó la inconstitucionalidad de una disposición provincial que obligaba a docentes y alumnos de los establecimientos educativos públicos a prestar juramento de lealtad a la bandera nacional así como a desarrollar otros actos de veneración de los símbolos nacionales. La decisión de la mayoría de los jueces fue la de rechazar la acción por razones de tipo formal que no tenían que ver con la libertad religiosa aducida para fundar la inconstitucionalidad. Sin embargo, uno de los jueces votó en el sentido de hacer lugar a la demanda y de reconocer la inconstitucionalidad de la referida norma, en tanto no reconocía la posibilidad de invocar la objeción de conciencia por parte de los individuos pertenecientes a grupos religiosos minoritarios que, como los Testigos de Jehová, tenían escrúpulos de conciencia que les impedían prestar tales actos de reverencia. Este voto consideró legítimo reconocer tal objeción para eximir a estos individuos de los actos de respeto activo (es decir, aquellos que suponen una conducta activa de parte del individuo), en la consideración de que los miembros del mencionado grupo no se oponían a los actos de respeto pasivo (mera abstención de agravio sin exteriorización de una conducta positiva de reverencia) ${ }^{98}$.

Veamos por último la objeción de conciencia en relación con la negativa a someterse a tratamientos médicos. La cuestión fue abordada por la Corte Suprema en el caso Bahamondez ${ }^{99}$. La situación era la siguiente: el señor Bahamondez había sido internado en el Hospital Regional de la ciudad de Ushuaia en razón de estar afectado por una hemorragia digestiva. En esas circunstancias se negó a recibir transfusiones de sangre por considerar que ello era contrario a las creencias del culto Testigos de Jehová que él profesaba. La Cámara de Apelaciones, al confirmar el pronunciamiento de la instancia anterior había sostenido que al ser el derecho a la vida el bien supremo, no resultaba posible aceptar que la libertad individual se ejerciera de modo tal que extinguiera la vida misma. Bahamondez recurrió ante la Corte Suprema y sostuvo que él no deseaba suicidarse, pero no deseaba tampoco aceptar un tratamiento médico contrario a sus convicciones religiosas.

\footnotetext{
97 Bidart Campos (1981), p. 588.

98 CSJN: sentencia de 9 de agosto de 2005, Fallos 328:2966, voto en disidencia de la jueza Highton de Nolasco.

99 CSJN: sentencia de 6 de abril de 1993.
} 
Consideró que la decisión de la Cámara avasallaba las garantías de libertad de culto y el principio de reserva.

La decisión de la Corte en este caso estuvo sumamente dividida. Una ajustada mayoría (cinco votos contra cuatro) consideró que la cuestión había devenido abstracta, y por lo tanto resultaba inoficioso cualquier pronunciamiento, pero tanto dentro de la opinión mayoritaria como de la minoritaria hubo votos particulares. El voto mayoritario fue simplemente que la cuestión era abstracta, porque a la fecha de la sentencia el interesado ya se había curado de sus dolencias ${ }^{100}$. Los dos votos concurrentes con la mayoría aceptaron el carácter abstracto del pronunciamiento, pero a pesar de ello decidieron aclarar que no se estaba frente a un caso que involucrara la libertad religiosa sino más simplemente del derecho de una persona a oponerse a un tratamiento médico sobre sí mismo, cualquiera que sea la motivación de la oposición. Este punto se encontraba claramente previsto en la ley sobre el ejercicio de la medicina que manda a los profesionales respetar la voluntad del paciente ${ }^{101}$.

Uno de los votos en disidencia consideró que la cuestión no era abstracta, dado que por la rapidez con que se produce el desenlace de este tipo de situaciones es muy difícil que, en la práctica, lleguen a estudio del Alto Tribunal las importantes cuestiones constitucionales que aquéllas conllevan sin haberse tornado abstractas. Para remediar esta situación correspondería establecer que resultan justiciables aquellos casos susceptibles de repetición, pero que escaparían a su revisión por estas circunstancias. Respecto del fondo, los jueces que mantuvieron esta disidencia votaron en el sentido de revocar la sentencia apelada, con fundamento en la libertad religiosa y de conciencia ${ }^{102}$. Un segundo voto en disidencia sostuvo, por las mismas razones, que el pronunciamiento no era inoficioso, pero decidió en el sentido de la revocación del pronunciamiento apelado con fundamento primariamente en el art. 19 de la Constitución que otorga al individuo un ámbito de libertad en el cual éste puede adoptar libremente las decisiones fundamentales, sin hacer referencia directa a la libertad religiosa ${ }^{103}$.

La opinión doctrinaria que comentó el caso, considerándolo como una verdadera objeción de conciencia (cuestión que, como vimos, no era clara) sostuvo la necesidad de respetarla como forma de garantizar la libertad de decisión en el ámbito de la integridad personal ${ }^{104}$.

100 CSJN: sentencia de 6 de abril de 1993, voto de los jueces Levene, Nazareno y Moliné O’Connor.

101 CSJN: sentencia de 6 de abril de 1993, voto de los jueces Fayt y Barra.

102 CSJN: sentencia de 6 de abril de 1993, voto de los jueces Cavagna Martínez y Boggiano.

103 CSJN: sentencia de 6 de abril de 1993, voto de los jueces Belluscio y Petracchi.

104 Bidart CAMPOS (1993), p. 253. 


\subsection{Los límites de la objeción de conciencia}

La invocación de objeción de conciencia resulta ser una conducta personal incluida como acción privada, aunque externa, en el ámbito de reserva del artículo 19. Ahora bien, como lo hemos reseñado, cuando la conducta de un hombre entra en interferencia con el orden y la moral pública o cuando perjudica a un tercero, sale ya del ámbito de las acciones privadas. Esos son, pues, los límites a la posibilidad de invocar la objeción de conciencia; en definitiva, los mismos límites que tiene la libertad religiosa considerada en sentido genérico. La objeción de conciencia es viable en tanto el deber eludido no sea de aquellos que pueden considerarse como básicos para la convivencia en común. Ella no puede ejercitarse si están en juego intereses fundamentales de la sociedad, de modo tal que en este caso tales intereses deben prevalecer sobre las cuestiones personales de conciencia.

Sin embargo, la interferencia estatal tiene que tener carácter absolutamente excepcional. Dada la importancia de este derecho humano que toca la interioridad de las personas, la restricción estatal debe ser la excepción y sólo cuando no exista otro medio similar para satisfacer los intereses sociales. De haberlos, corresponde su empleo alternativo a fin de resguardar la conciencia personal ${ }^{105}$.

\section{BREVE CONCLUSIÓN}

En este trabajo se ha realizado un rápido repaso del derecho constitucional argentino en lo tocante a la libertad religiosa, tanto en el modo en que ella aparece delineada en el propio texto constitucional como en las especificaciones que han sido establecidas en normas de rango legal y en la jurisprudencia de la Corte Suprema de Justicia de la Nación. Puede decirse que late detrás de este conjunto normativo un sistema auténticamente liberal que busca resguardar el pluralismo religioso de la sociedad argentina.

En efecto, la Constitución adopta una concepción personalista en virtud de la cual el Estado es un epifenómeno de la sociedad, o sea, un reflejo que está al servicio de ésta. De allí el generoso reconocimiento de la libertad religiosa del individuo, y la limitación de la injerencia estatal al mínimo posible, es decir, sólo justificada en cuanto ello sea indispensable para preservar el orden y la moral pública, o salvar los derechos de los terceros ${ }^{106}$.

En otras palabras, en el sistema constitucional argentino y en relación con el tema que se ha estudiado, la regla es el ámbito de libertad; la restricción a esa

105 Gelli (2005), p. 137.

106 VANOSSI (1981), p. 592. 
libertad (por razones de orden público) resulta estrictamente excepcional. Como se ha dicho más arriba, la libertad religiosa no puede ser coaccionada si no hay un bien jerárquicamente superior que lo exija ${ }^{107}$.

\section{BibLIOGRAFíA CITADA}

AlbANeSE, Susana (1988): "El objetor de conciencia y la tendencia actual en la comunidad internacional”, en Revista El Derecho (número 129), pp. 800-806.

Albanese, Susana (2007): "El control de convencionalidad. La Corte Interamericana y la Corte Suprema: convergencias y divergencias", en Revista Jurisprudencia Argentina (número 2007-III), pp. 1148-1150.

Álvarez, Osvaldo Onofre (1989): "El servicio militar, la libertad de conciencia y un fallo controvertido", en Revista El Derecho (número 133), pp. 381-387.

Bermúdez, Horacio Ricardo (2007): "La libertad religiosa en la Constitución Nacional”, en Bosca, Roberto; NAVARro Floria, Juan (compiladores): La libertad religiosa en el derecho argentino (Buenos Aires, Consejo Argentino para la Libertad Religiosa y Konrad-Adenauer-Stiftung), pp. 75-118.

Bidart Campos, Germán (1981): "Derecho de aprender, libertad religiosa y 'derecho al silencio", en Revista El Derecho (número 90), pp. 588-592.

Bidart CAMPOS, Germán (1983): "La objeción religiosa de conciencia y el deber militar de defensa (¿igualdad de derechos y deberes?)", en Revista El Derecho (número 104), pp. 736-743.

BidART CAMPOS, Germán (1988): Tratado elemental de derecho constitucional argentino (Buenos Aires, Editorial EDIAR), tomo I.

Bidart Campos, Germán (1991): "Objeción religiosa de conciencia al voto obligatorio”, en Revista El Derecho (número 142), pp. 556-557.

Bidart Campos, Germán (1993): "La objeción de conciencia frente a los tratamientos médicos", en Revista El Derecho (número 153), pp. 253-254.

Bidart Campos, Germán (1998): Manual de la Constitución Reformada (Buenos Aires, Editorial EDIAR), tomo I.

Bureau Of Democracy, Human Rights And Labor - United States Department Of StATe (2011): Argentina 2010, informe sobre la libertad religiosa en Argentina (consultado el 27 de septiembre de 2011), disponible en <http://www. state.gov/documents/organization/171765.pdf>.

ChAVEs, Diego (2005): "La reglamentación de la libertad religiosa en el derecho argentino”, en Revista El Derecho (número 214), pp. 943-947.

107 Bidart Campos (1983), p. 736 
Dalla Vía, Alberto R. (1989): "El caso Portillo y el derecho a la objeción de conciencia en el derecho argentino", en Revista El Derecho (número 133), pp. 387-393.

Gelli, María Angélica (2005): Constitución de la Nación Argentina comentada y concordada (Buenos Aires, Editorial La Ley).

Gentile, Jorge Horacio (2003): "Por qué una ley de libertad religiosa", en BoscA, Roberto (compilador): La libertad religiosa en Argentina (Buenos Aires, Consejo Argentino de Libertad religiosa y Konrad-Adenauer-Stiftung), pp. 47-82.

Gentile, Jorge Horacio (2007): "La libertad religiosa en las provincias y en la ciudad de Buenos Aires", en Bosca, Roberto y Navarro Floria, Juan (compiladores): La libertad religiosa en el derecho argentino (Buenos Aires, Consejo Argentino de Libertad religiosa y Konrad-Adenauer-Stiftung), pp. 119-162.

Gramajo, Juan Manuel (2007): "Los acuerdos celebrados entre la República Argentina y la Santa Sede", en Bosca, Roberto y Navarro Floria, Juan (compiladores): La libertad religiosa en el derecho argentino (Buenos Aires, Consejo Argentino de Libertad religiosa y Konrad-Adenauer-Stiftung), pp. 63-74.

Herrendorf, Daniel E. (1989): "Quien no quiere morir a los 20 años no tiene porqué depositar su fe en las armas", en Revista El Derecho (número 133), pp. 371-378.

HitTers, Juan Carlos (2009): "Control de constitucionalidad y control de convencionalidad. Comparación (criterios fijados por la Corte Interamericana de Derechos Humanos)", en Estudios Constitucionales (número 2), pp. 109-128.

Jiménez, Eduardo Pablo (2000): Derecho constitucional argentino (Buenos Aires, Ediar), tomo II.

Navarro Floria, Juan (2004): El derecho a la objeción de conciencia (Buenos Aires, Ábaco).

NAVARRO Floria, Juan (2005): "Algunas cuestiones actuales de derecho eclesiástico argentino", en Anuario de derecho eclesiástico del Estado (número 21), pp. 301-325.

Navarro Floria, Juan (2007): "La libertad religiosa en el Derecho Privado", en Bosca, Roberto y NaVARRo Floria, Juan (compiladores): La libertad religiosa en el derecho argentino (Buenos Aires, Consejo Argentino de Libertad religiosa y Konrad-Adenauer-Stiftung), pp. 243-264.

Navarro Floria, Juan (2011): Acuerdos y concordatos entre la Santa Sede y los países americanos (Buenos Aires, EDUCA). 
Padilla, Miguel M. (1993): Lecciones sobre derechos humanos y garantías (Buenos Aires, Editorial Abeledo Perrot), tomo II.

Padilla, Norberto (2009): Ley de libertad religiosa: 'la historia que he vivido', conferencia en la Jornada organizada por el Consejo Argentino para la Libertad Religiosa, Buenos Aires, 22 de septiembre de 2009 (consultado el 27 de septiembre de 2011), disponible en <http://www.calir.org.ar/docs/NorbertoPadillaHistoriasobrelosproyectosdeleydeLR092009.pdf>.

Quiroga Lavié, Humberto; Benedetti, Miguel Ángel; Cenicacelaya, María de las Nieves (2009): Derecho Constitucional Argentino (Buenos Aires, Editorial Rubinzal-Culzoni).

Relator Especial De Las Naciones Unidas Para la Libertad De Religión Y De Creencias (2002): Civil and Political Rights. Report submitted by Mr. Abdelfattah Amor, in accordance with Comision on Human Rights resolution 2001/42. Addendum, visit to Argentina, Documento E/CN.4/2002/73/ Add.1 de la Comisión de Derechos Humanos (consultado el 27 de septiembre de 2011), disponible en <http://www.unhchr.ch/Huridocda/Huridoca. nsf/0/ba2ba2d948c9334ec1256bb80049a972/\$FILE/G0210147.pdf>.

SAGÜÉs, Néstor P. (1997): Elementos de derecho constitucional (Buenos Aires, Editorial Astrea), tomo II.

VAnossi, Jorge R. (1981): "A propósito de la libertad religiosa y los límites constitucionales del pluralismo", en Revista El Derecho (número 90), pp. 592-598.

\section{REFERENCIAS DE NORMAS CITADAS ${ }^{108}$}

Constitución de la Nación Argentina.

Declaración Universal de Derechos Humanos.

Declaración Americana de Derechos y Deberes del Hombre.

Convención para la Prevención y Sanción del Delito de Genocidio, aprobada por decreto-ley 6286/56. Boletín Oficial (BO) 4 de septiembre de 1956.

Acuerdo entre la Santa Sede y la República Argentina, aprobado por ley 17032. BO, 22 de diciembre de 1966.

Convención para la Eliminación de todas las formas de Discriminación Racial, aprobada por ley 17722. BO, 8 de mayo de 1968.

${ }^{108}$ Sólo se incluyen en la lista las referencias normativas citadas que están en vigor. No se incluyen las normas no vigentes que han sido citadas con finalidad de ilustración histórica. 
Convención Americana de Derechos Humanos, aprobada por ley 23054. BO, 27 de marzo de 1984.

Convención para la Eliminación de todas las formas de Discriminación contra la Mujer, aprobada por ley 23173. BO, 3 de junio de 1985.

Pacto Internacional de Derechos Civiles y Políticos, aprobado por ley 23313. BO, 13 de mayo de 1986.

Pacto Internacional de Derechos Económicos, Sociales y Culturales, aprobado por ley 23313. BO, 13 de mayo de 1986.

Convención contra la Tortura y otros Tratos o Penas Crueles, Inhumanos o Degradantes, aprobada por ley 23338. BO, 26 de febrero de 1987.

Convención de los Derechos del Niño, aprobada por ley 23849. BO, 22 de octubre de 1990.

Ley 340, Código Civil. Sancionada 25 de septiembre de 1859, RN 1863/69, p. 513.

Ley 346, de ciudadanía. Sancionada 1 de octubre de 1869, RN 1863/69, p. 517.

Ley 11179, Código Penal. BO, 3 de noviembre de 1921 (texto ordenado en 1984).

Ley 20744, de contrato de trabajo. BO, 27 de septiembre de 1974.

Ley 21745, del Registro Nacional de Cultos. BO, 15 de febrero de 1978.

Ley 23298, Ley Orgánica de los Partidos Políticos. BO, 25 de octubre de 1985.

Ley 23551, de sindicatos. BO, 22 de abril de 1988.

Ley 23592, sobre ejercicio de derechos y garantías constitucionales y medidas contra actos discriminatorios. BO, 5 de septiembre de 1998.

Ley 24429, sobre servicio militar voluntario. BO, 10 de enero de 1995.

Ley 24483 , sobre sociedades de vida apostólica e institutos de vida consagrada.

BO, 4 de mayo de 1995.

Ley 24571, sobre días no laborables para quienes profesen la religión judía. BO, 30 de octubre de 1995.

Ley 24660, sobre penas privativas de la libertad. BO, 16 de julio de 1996.

Ley 24757, sobre días no laborables para quienes profesen la religión musulmana.

BO, 2 de enero de 1997.

Ley 25151, sobre paga de los días festivos de trabajadores judíos y musulmanes.

BO, 14 de septiembre de 1999.

Ley 25164, Marco de Regulación del Empleo Público Nacional. BO, 8 de octubre de 1999.

Ley 25212, Pacto Federal del Trabajo. BO, 6 de enero de 2000. 
Ley 26206, de Educación Nacional. BO, 28 de diciembre de 2006.

Decreto 2037/79, sobre funciones del Registro Nacional de Cultos. BO, 4 de septiembre de 1979.

\section{REFERENCIAS DE JURISPRUDENCIA CITADA}

Contra el Presbitero Jacinto Correa, por infracción del art. 118 de la ley de matrimonio civil de 12 de noviembre de 1888 (110 de la ley de 12 de noviembre de 1889) (1893): Corte Suprema de Justicia de la Nación (CSJN) 29 de julio de 1893, en Fallos, tomo 53, p. 188.

Didier Desparats, Gabriel José(1928): CSJN 1928 (en la base de datos del tribunal sólo figura el año, pero no la fecha exacta de la sentencia), en Fallos, tomo 151, p. 403.

Esquivel, Héctor Dario (1933): CSJN 1933 (en la base de datos del tribunal sólo figura el año, pero no la fecha exacta de la sentencia), en Fallos, tomo 168, p. 130.

Moxey, Edwin Patrick (1945): CSJN 1945 (en la base de datos del tribunal sólo figura el año, pero no la fecha exacta de la sentencia), en Fallos, tomo 201, p. 406.

Agüero, Carlos c/Universidad Nacional de Córdoba (1949): CSJN 1949 (en la base de datos del tribunal sólo figura el año, pero no la fecha exacta de la sentencia), en Fallos, tomo 214, p.139.

Rudman, Moisés y otros (1959): CSJN 1959 (en la base de datos del tribunal sólo figura el año, pero no la fecha exacta de la sentencia), en Fallos, tomo 245, p. 421.

Glaser, Benjamin Abel (1966): CSJN 23 de septiembre de 1966, en Fallos, tomo 265, p. 336.

Watch Tower Bible and Tract Society (Testigos de Jehová) c/Estado Nacional (1977): CSJN 22 de diciembre de 1977, en Fallos, tomo 299, p. 352.

Asociación Dúo o Asociación de la Luz Divina o Asociación Mundial de Ayuda Social (1978): CSJN 14 de diciembre de 1978, en Fallos, tomo 300, p.1263.

Barros, Pablo A. y otro c/Consejo Nacional de Educación (1979): CSJN 6 de marzo de 1979, en Fallos, tomo 301, p. 151.

Carrizo Coito c/Dirección Nacional de Migraciones (1980): CSJN 26 de junio de 1980, en Fallos, tomo 302, p. 604.

Kirchner, Carlos y otros (1980), Suprema Corte de Justicia de la Provincia de Buenos Aires 2 de septiembre de 1980, en Revista El Derecho, tomo 90 (1981), p. 589. 
Carbonell, Luis Alberto (1982): CSJN 12 de agosto de 1982, en Fallos 304:1139.

Lopardo, Fernando G. s/insubordinación (1982): CSJN 26 de octubre de 1982, en Fallos, tomo 304, p. 1524.

Falcón, Javier Ignacio (1983): CSJN 21 de junio de 1983, en Fallos, tomo 305, p. 809.

Sejean, Juan B. clZaks de Sejean, Ana M. s/inconstitucionalidad del art. 64 de la ley 2393 (1986): CSJN 27 de noviembre de 1986, en Fallos, tomo 308, p. 2268.

Ignacio Villacampa c/María Angélica Almos de Villacampa (1989): CSJN 9 de febrero de 1989, en Fallos, tomo 312, p. 122.

Portillo, Alfredo s/infracción art. 44 ley 17531 (1989): CSJN 14 de abril de 1989, en Fallos, tomo 312, p. 496.

Martín, Patricia slqueja en autos: Pieroni, Amadeo R. y otros (1991): Cámara Nacional Electoral 21 de agosto de 1991, en Revista El Derecho tomo 142 (1991), p. 555.

Lastra, Juan c/Obispado de Venado Tuerto (1991): CSJN 22 de octubre de 1991, en Fallos, tomo 314, p. 1324.

Rybar, Antonio c/García, Rómulo y/u Obispado de Mar del Plata (1992): CSJN 16 de junio de 1992, en Fallos, tomo 315, p. 1294.

Bahamondez, Marcelo s/medida cautelar (1993): CSJN 6 de abril de 1993, en Fallos, tomo 316, p. 479.

Sisto, Verónica y Franzini, Martín s/información sumaria (1998): CSJN 13 de agosto de 1998, en Fallos, tomo 321, p. 92.

Asociación de Testigos de Jehová c/Consejo Provincial de Educación del Neuquén s/ acción de inconstitucionalidad (2005): CSJN 9 de agosto de 2005, en Fallos, tomo 328, p. 2966. 